\title{
Review
}

\section{The Importance, Unexploited Opportunities and Challenges of Vermicomposting Technology in Ethiopia.}

\author{
Tadie Girma Dadi ${ }^{1}$ and Hana Tamrat Gebirehiwot ${ }^{2}$
}

\author{
${ }^{1}$ Department of Natural Resource Management, Salale University, Fitche, P.O.B.245, Ethiopia; tadegirma19@gmail.com \\ ${ }^{2}$ Department of Natural Resource Management, Salale University, Fitche, P.O.B.245, Ethiopia; hanatamrat87@gmail.com \\ *Correspondence: tadie_girma@slu.edu.et; +251900006030
}

\begin{abstract}
Agriculture is the mainstay of the Ethiopian and a key sector of its economy. However, Lack of productive and environmentally friendly technology is not widely applicable elsewhere. Likewise, the vermicomposting technology is a recently emerging science which not effectively transferred to the users across the country. Thus, this review is aimed to shine the importance, unexploited opportunities and the challenges hindered for further expansions in Ethiopian context. Vermicompost is among the powerful organic fertilizers which enhance soil Fertility and productivity. As agrarian society; there are plenty of raw byproducts and weed species which are not center of focus (i.e cattle waste, crop residues and invasive weeds like P.Juliflora, P.hysterophorus and E.crassipes respectively). However, there are many constraints there like policy issue, handling problems and sensitivity of the worms for different environmental factors which hindered to invest on a wide range. Generally, the number and weight of vermiculture as well as amount of produced casts are promised and every possible ways were recommended to entertain on the large scale.
\end{abstract}

Keywords: Invasive weeds, Organic Fertilizers,Vermicomposting Technology, Ethiopia.

\section{Introduction}

Soil is a necessarily important Natural Resource. As most of Ethiopia farmers' belief soil is a life. Hence, the efficient management of which is vital for economic growth and development for the production of food, fiber and other necessities. If management for natural resource is must; the priority should be given to soil for several reasons. Agriculture is still characterized by low productivity, a high level of nutrient mining, low use of external inputs, traditional farm management practices and limited capacity to respond to environmental shocks [1,2]. According to [3] finding, $342 \mathrm{~km} 2$ of Ethiopian land is exposed for soil erosion and of this 31\% is already eroded out of entire land of the country. On the densely-populated highlands, a growing number of low-income smallholders depend heavily on soil nutrients for food and biomass for energy, meaning that everything produced from the soil is used as far as possible and very little remains to re-invest in soil replenishment or inputs for the following year. If amount of nutrient lose is more and other input is less, it needs balanced proportion which tend to add organic or inorganic fertilizers. [4] Report shown Organic fertilizer impact is broad; it improves organic carbon and nutrient levels, nutrient retention, reduced topsoil erosion, and mitigated acidity and salinity. However, this review is specifically; focus on vermi-compost among many others organic fertilizers which been used to maintain soil fertility.

Vermicomposting is a bioconversion process where earthworms feed on the organic waste to produce more earthworms and vermi-composts products. According to [5], the vermi-compost have visible promised impacts on some chemical properties of soil and plant growth like Organic Matter, Exchangeable Potassium, Available Phosphorus, Total Nitrogen and Sulphur element content and increasing plant height and leaf number respectively when compared to farm soils. As vermicomposting is newly emerging technology in Ethiopia this paper is most likely emphasis on compiling different recent scientific outputs on this technology.

Vermicomposting is a bioconversion process where earthworms feed on the organic waste to produce more earthworms and vermi-composts products. According to [5], the vermi-compost have visible promised impacts on some chemical properties of soil and plant growth like Organic Matter, Exchangeable Potassium, Available Phosphorus, Total Nitrogen and Sulphur element content and increasing plant height and leaf number respectively when compared 
to farm soils. As vermicomposting is newly emerging technology in Ethiopia this paper is most likely emphasis on compiling different recent scientific outputs on this technology.

The methodological approach adopted was literature search, which was carried out using the following search engines and platforms: Web of Science Research Gate, Google Scholar (scholar.google.com), and AGRIS (agris.fao.org). Related dissertations sourced from different archives were also used for this review. Literatures published up to June, 2020 were used as the latest information. Generally published books, journals, proceeding papers and unpublished papers were used. Among this $87 \%$ of referred papers were focused on Ethiopia. Thus, the aim of this review is to revealing the main importance of vermicomposting from recent documented materials, positing the untapped opportunities to apply vermicomposting in Ethiopian and to unveil different challenges which hindering the technology to apply on wide range.

\section{Importance of Vermicomposting Technology in Ethiopia}

\subsection{Soil Fertility Enhancement and Crop Yield improvement}

According to [6] the soil physical properties like soil bulk density and porosities were tended to decrease and increase respectively as rate of added vermi-compost was increased. Besides, the concentration of micro nutrient elements (Iron, Zink, Manganese and Cupper) and Exchangeable bases (Magnesium and Calcium) also increased along with the increment of vermi-compost rate to certain level.[7], research output also pointed out that; the Vermi-compost gained soil had recorded from moderate to very high rate for selected soil chemical properties (See Table 1).

Table 1: Chemical Properties of vermi-compost

\begin{tabular}{llllllll}
\hline \multicolumn{7}{c}{ Chemical Properties } \\
\hline No. of & Total & Available & Exchangeable & $\mathrm{OM}(\%)$ & $\mathrm{OC}(\%)$ & $\mathrm{pH}$ & $\mathrm{EC}(\mathrm{ms} / \mathrm{m})$ \\
VC & $\mathrm{N}(\%)$ & $\mathrm{P}(\mathrm{mg} / \mathrm{kg})$ & $\mathrm{K}(\mathrm{Cmol}(+) / \mathrm{kg}$ & & & & \\
\hline Value & 0.56 & 25.82 & 23.69 & 15.39 & 8.92 & 7.25 & 8.83 \\
Rating & Very high & Moderate & Very high & Very high & Very high & Neutral & Very high \\
\hline
\end{tabular}

Source: [7]

Similarly, [8] revealed promising result on some soil chemical properties like soil pH, Organic Carbon, Organic matter, Total Nitrogen and Exchangeable bases in Tigray region, Ethiopia. The finding of [9] also shown the significance of vermi-compost in increasing the Available Phosphorus, Organic Carbon, Total Nitrogen, Exchangeable Magnesium and Cation Exchange Capacity when compared to conventional compost .The application of composts and vermi composts improves the organic content and plant available nutrients, enhances the microbial activity and humus content of the soil, and helps to improve the soil structure, water holding capacity and also a sustainable supply of macro and micro nutrients [10].

Vermi-compost has a vital role in increasing the productivity of the soils: Implies the yield/ha/year. According to [11], the integrated application of vermi-compost and Rhizobium inoculation was boosted the faba bean yield in low fertile soils. In addition, they proved that, the significant increase of total plant Phosphorus uptake and total plant Nitrogen accumulation by increasing vermi-compost application. [7] Research output showed that, how vermi-compost increased the growth parameters of garlic (Allium Sativum L.) like leaf area index, garlic bulb dry matter and fresh biomass at Haramaya District of Ethiopia (See Table 2).

Table 2: Effects of application of vermi-compost on days to emergency, fresh biomass(FB), total dry matter, leaf area, leaf area index (LAI), and Total soluble solid (TSS) of garlic.

\begin{tabular}{llllllll}
\hline Factor & treatment & $\begin{array}{l}\text { Days to emergency } \\
(\text { days })\end{array}$ & $\mathrm{FB}(\mathrm{g})$ & $\begin{array}{l}\text { Total dry } \\
\text { matter }(\%)\end{array}$ & Leafarea $\left(\mathrm{cm}^{2}\right)$ & LAI & TSS $\left(\mathrm{Brix}^{0}\right)$ \\
\hline & 0 & $10.13^{\mathrm{c}}$ & $56.19^{\mathrm{c}}$ & $27.01^{\mathrm{c}}$ & $30.32^{\mathrm{c}}$ & $0.87^{\mathrm{c}}$ & $11.92^{\mathrm{d}}$ \\
$\mathrm{VC}(\mathrm{t} / \mathrm{ha})$ & 2.5 & $9.00^{\mathrm{b}}$ & $59.05^{\mathrm{b}}$ & $29.18^{\mathrm{b}}$ & $32.37^{\mathrm{bc}}$ & $1.03^{\mathrm{b}}$ & $12.27^{\mathrm{c}}$
\end{tabular}




\begin{tabular}{llllllll} 
& 5 & $8.67^{\mathrm{b}}$ & $60.08^{\mathrm{ab}}$ & $31.37^{\mathrm{a}}$ & $33.99^{\mathrm{b}}$ & $1.12^{\mathrm{b}}$ & $12.45^{\mathrm{b}}$ \\
& 7.5 & $8.07^{\mathrm{a}}$ & $61.54^{\mathrm{a}}$ & $32.71^{\mathrm{a}}$ & $37.05^{\mathrm{a}}$ & $1.36^{\mathrm{a}}$ & $12.72^{\mathrm{a}}$ \\
\hline LSD(0.05) & 0.50 & 2.29 & 1.50 & 2.48 & 0.09 & 0.08 \\
$\mathrm{CV} \%$ & & 5.76 & 3.96 & 5.09 & 7.57 & 8.79 & 0.67 \\
\hline
\end{tabular}

Source:[7]

$[12,13]$ Research result shown, the combined application of vermi-compost with other inorganic fertilizer is promising in improving the crop physiological maturity like panicle length, plant height, grain yield, harvest index, straw yield and total biomass of the crop when compared to control and sole treated groups. According to [2] finding, the highest grain yield of bread wheat $(4695 \mathrm{~kg} / \mathrm{ha}$ ) was obtained from the application of half dose of the recommended rate of vermi-compost and half dose from inorganic NP fertilizer which gave grain yield advantage of $504 \mathrm{~kg} / \mathrm{ha}$ compared to application of full dose of the recommended rate of vermi-compost alone as N equivalence (4191kg/ha). Similarly,[14], posited the use of half recommended N from vermi-compost and NP from inorganic fertilizer could produce better mean grain yield of maize production and productivity in Assosa. More so, as rate of nitrogen $(\mathrm{N})$ and vermi-compost addition increase the kernel weight/heads, harvest index and grain yield of sorghum increase to certain extent in Fadis District, eastern Ethiopia [15]. [16] Revealed that numbers of umbels per plant, umbel diameter, number of seeds per umbel and seed weight per umbel were significantly affected by the main effect of NP fertilizer rates and vermicompost. At the same times, the highest seed yield per hectare $(1462.5 \mathrm{~kg} / \mathrm{ha})$ was obtained from the plants grown at $75 \%$ of RDF with vermicompost at $2.5 \mathrm{t} /$ ha which was about $263 \%$ higher than seed yield from unfertilized control plot.

\subsection{Reduce Green House Gas (GHG) emissions}

Climate change causes prolonged droughts and erratic rainfall, which in turn leads to, a reduced water retention capacity of the soil, increased erosion and biodiversity loss [17]. The main cause root for climate change is the hazardous gases released to the air from different sectors. Ethiopia Green House Gas (GHG) emission is dominated by Agriculture which accounts about $80 \%$ of total Green House Gas (GHG) emissions (Figure 1).

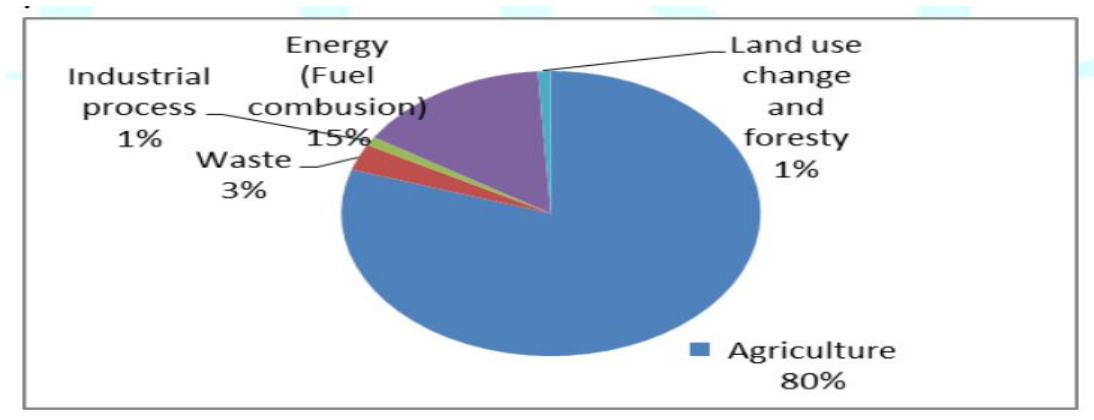

Figure: 1 Total greenhouse gases emission by sectors in 1994

Source: [20]

To cope up this problem, vermicomposting technology is solely a beneficial option when compared to thermo-composting which increases the $\mathrm{CO}_{2}$ production or landfilling with the emissions of $\mathrm{CH}_{4}$ which supporting in mitigating climate change impacts via its sustainable aesthetics in solid waste management [18]. Numerous solutions have been identified for reducing Nitrogen losses and $\mathrm{CO}_{2}$ Green House Gas emissions; however the existing technologies are harder to apply in developing countries like Ethiopia because they are expensive and difficult to upscale to larger systems. Vermicomposting, on the other hand, is low cost method, making it feasible for many resource poor farmers to produce high fertilizing value compost and reduces total Nitrogen loss, $\mathrm{CH}_{4}$ and $\mathrm{N}_{2} \mathrm{O}$ emissions compared with thermophilic composting methods [19]. Furthermore, higher earthworm abundance reduces $\mathrm{CH}_{4}$ emissions and accelerates the decomposition process. Vermicomposting provide multiple benefits: reduced waste management costs and emissions, create employment and other public health benefits, reduce use of chemical fertilizer, which is associated with large $\mathrm{CO}_{2}$ emissions during manufacture and transport, and $\mathrm{N}_{2} \mathrm{O}$ releases (Nielsen et al., 1998 as cited in [21]. 


\subsection{Role of vermi-compost in ecosystem management}

Disposal of uncontrolled solid waste was among the major causes of surface water like river pollution in the case of Shankila, Kebena and Akaki River [22, 23]. Consequently, this leads to eutrophication of the aquatic system as in the case of Aba Samuel Dam [24]. Similarly, inappropriate way of solid waste disposal on terrestrial environment will cause land abuse. Therefore, vermin-culture is a nature based solution to convert the cost of the inappropriate way of solid waste disposal to benefit. Since earthworm act enhances natural biodegradation and decomposition of organic wastes which originate from homes, gardens, dairies and farms [25]. The production of vermicompost is easily acceptable and adoptable by the small scale farming community without much input cost. The vermicompost production is very much useful to make use of solid waste and other organic wastes to make nutrient rich humus. The application of vermicompost is surely effective alternative nutrient for the resource poor farming community to grow their crops without polluting the environment [26]. Vermi-compost has the capacity to remediate the soil ecology through reducing the heavy micronutrient which inhibited the plant growth due to their surplus required amount. The vermicomposting process offers a more affordable bio fertilizer as an alternative to chemical fertilizers and enhances productivity, improved soil fertility, nutritional and food security. Additionally, the system provides a more cost-efficient biological way to manage organic waste generated from agricultural processing industries thus, minimizing the waste burden on the environment.

\subsection{Improve adaptability of crop for soil born disease}

Vermi-compost has the capacity to suppress the legume plant disease like aphids and psyllids when compared with inorganic fertilizer treated plants [26]. According to [8] report, the women farmers perceived vermi-compost reduced infestation by hazardous weeds (e.g. striga), insects (e.g. stock borer) as well as plant diseases such as rust. Vermi-compost treated Maize also tolerated the incidence of rust disease as well as stock borer when compared to chemical fertilizer treated farms. [27] Outlined compost tea produced as a non-aerated, water ferment of composted agricultural wastes comprising maize and wheat straw, chopped grasses, ash, and animal manure substrates has potential to manage the diseases. The microbial diversity of Non-aerated compost teas, especially bacterial diversity, appears to contribute to the level of disease suppression. Further study by [26] also shown that the pest suppression potential of vermicompost treated horticultural crop particularly in cabbage.

\subsection{Reduce Farmers and Government Financial Risk to Provide Inorganic Fertilizers}

In Ethiopia, 3.2mha of land is available for agriculture which accounts about $75 \%$ of total exports and contributes a good percentage towards GDP (45\%) of the country. The common chemical fertilizers being used are NPK $(100,50,100)$ $\mathrm{kg} / \mathrm{ha} /$ year and their average cost is 100US\$ while Bio fertilizers like vermicompost, Poultry manure, Farm yard Manure $(5,5,30)$ ton/ha/year respectively with average cost of 40US\$. In General Organic farming is $40.6 \%$ more economical, environmentally soundable and socially acceptable than inorganic farming [28]. The total estimated cost of crop production per hectare per year for organic farming was US\$ 190 (1634 Ethiopian Birr) and for inorganic farming, it was US\$ 320 (2752 Ethiopian Birr). Fields that received organic compost (Vermicompost) may not need a fertility enhancing input in the following year. This is the way of saving the end users from unwanted cost. Thus, Farmers are able to reduce production costs by relying on renewable local resources that, at the same time, improve environmental services and increase yields [29]. Detailed study by [8] emphasis, women farmers in Tigray Region, produced and sold $1 \mathrm{~kg}$ of vermicompost and Vermi-worm in 10 and 250 Ethiopian birr on average respectively.

$[30,7]$ Research output showed the farmers benefit cost is increased as the rate of applied vermicompost increase from 0 to $7.5 \mathrm{t} / \mathrm{ha}$. Thus, it can be reasonably generalized that on short time basis, the application of high amounts of Vermi-Compost fertilizers can result in higher economic return than the low dose of Vermicompost fertilizer. [16], also recommended the combined application of inorganic fertilizers at 75\% RDF with Vermicompost at 2.5t/ha to get higher economic benefit from onion (Allium cepa L.). In General, producing vermicompost from organic waste material could be reducing the chemical fertilizers and lead to sustainable agriculture. Furthermore, it can be considered as an entrepreneurship for the youth and farmers, thereby an economic and ecofriendly method can be developed [31]. 
[32] Research finding shown, as many fertilizer combination alternatives need the farmers input (intensive labor) affordability even if they are good in increasing the yield. For instance, from their experiment the highest values for the yield parameters were recorded when 8 ton/ha vermi-compost was applied in combination with $50 \%$ recommended mineral fertilizer for tomato vegetable. However, the higher economic return was recorded at the application of 4 ton/ha vermicompost combined with $50 \%$ mineral fertilizer and it's economically affordable for farmers to adopt easily than 8 ton/ha with 50\% mineral fertilizers. [33] finding also shown adequate and inclusive House Hold waste management practice would become means to generate income for resource poor House Holds; and micro and small enterprises working on urban agriculture.

\section{Unexploited Opportunities to Perform Vermicomposting Technology in Ethiopia}

\subsection{Recycling of Biodegradable waste products for vermicompost Production}

Ethiopia is among developing countries which have no scientific based ground to reuse the biodegradable organic wastes releasing from different limited Industries, Municipal and Agriculture activities. The organic and biodegradable waste released from towns are accounts large volume when compared with other physical compositions of solid wastes. Those wastes or/and residuals are primarily used as source of energy, shelter construction and cattle fodder. However, the amount of unwisely throwing away of those resource is the major problem at national level. Thus, using those waste raw materials like khat, coffee husk, enset and cereal crop residue by endorsing ecofriendly technologies like vermicomposting to across the country is very crucial.

For instance Khat (Catha edulis) is a predominant cash crop in eastern and south western part of the country. There are commonly known khat growing, export and transport routes across the country as shown on the (Figure 2).

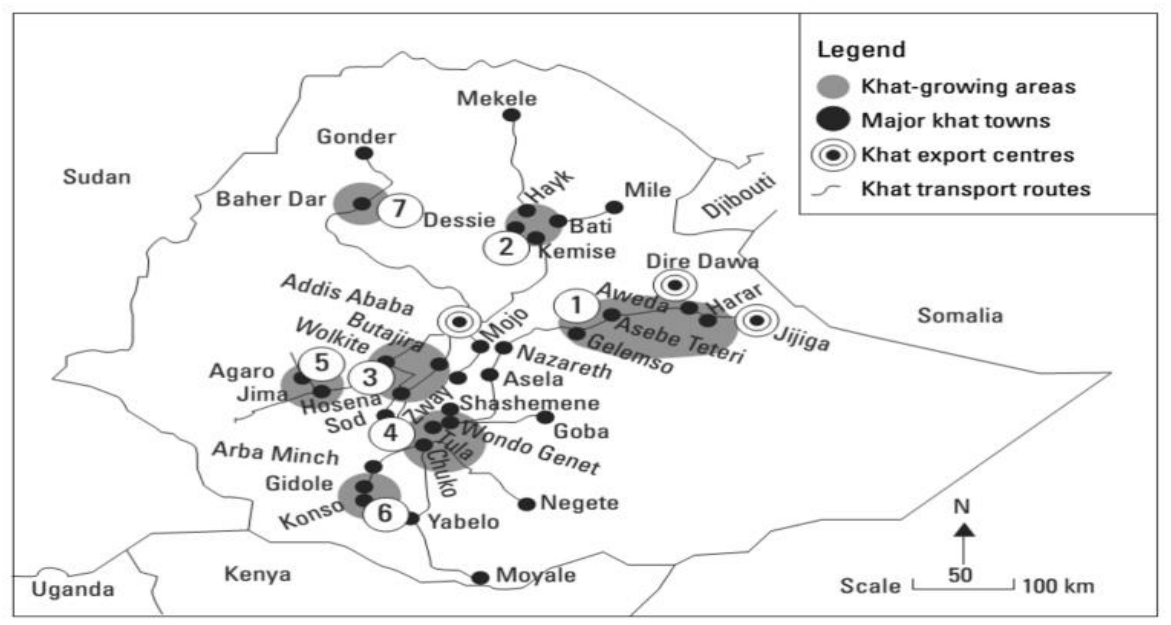

Figure 2: Common Khat growing regions in Ethiopia

Source: [34]

During 2009-2010 alone, the export value of this plant increased by $51 \%$, while coffee increased $40 \%$ and leather products were down by $25.4 \%$ (Fortune 2010 as cited in [34]. On the other hands waste of domestically consumed khat (Catha Edulis) is been used for non-aerated compost production purposes. [35] posited that waste vermicompost is improved the nutrient content of Total Nitrogen, Available Phosphorus and Available Potassium by 95\%, 76\% and 69\% respectively when compared to the control groups. As drawback, the $\mathrm{pH}$ value of the khat waste vermicompost is alarmly declined due to the organic acid release during mineralization of raw waste materials. About 85\% of Ethiopians are depending on agriculture (Cultivation, Pastoralism and Mixing of the both practice).

From the center to highlands area of the country is predominantly based on cereal crop production which their residual part is used for biofuel and cattle fodder. By investing the knowledge and technology it is possible to boost the passion of having organic fertilizers. To realize this dream Maize stalk, Khat and stevia leaves, and fresh food scraps were best to least feed materials for earthworm multiplication. [12] Research output showed that, the high number of 
worms was obtained by feeding worms on maize stalk, whereas the lowest worm number was obtained on fresh food scraps. Furthermore, the highest cast was also produced from worms fed with maize stalk, while the lowest cast was produced from worms fed with fresh food scraps. Therefore, maize stalk, chat wastes, stevia and fresh food scraps were also best to least bedding materials for cast production with exotic ambo worm when compared with Meskan and Zway local worms. The aeration system in food scraps may increase the worm's mortality rate and declining the cast production when compared with other residuals. Enset is also, the perennial crop which widely used for human consumption in southwestern part of Ethiopia. The waste of this organic plant is also used for different purposes like vermicompost production. [35], pointed out that, the Enset vermicompost is increased Total Nitrogen, Available Phosphorus and Available Potassium by $84 \%, 93 \%$ and $56 \%$ respectively when compared to the control groups.

\subsection{Converting of Invasive weeds to vermicompost Resources}

The most challenging invasive weeds like Lantana Camara L., Prosopis Juliflora, Parthenium hysterophorus and Water hyacinth (Eichhornia crassipes) which engulfing the central valley of Awash basin should be managed through [36] "Eradication by Utilization" principle which mean economic exploitation of invasive species as a means of harnessing their economic potentials for meeting basic human needs and at the same time control its spread and possibly eradicate them. Thus, One of the possible options to manage Lantana camara L. and Prosopis Juliflora invasions are through utilization for the production of biogas, compost especially vermicompost [37], and as a green manure. [38] Reveled as Parthenium hysterophorus has become a notorious weed since its discovery in the 1980's in Ethiopia.

It has been spreading from the eastern route of Ethiopia along the Dire Dawa, Addis Ababa railway presumably between 1974 and 1980. Some believe that the weed might have been transported into the country with imported or donated grain. In the Amhara region, it is estimated that about 37,105ha of land is infested with Parthenium hysterophorus. Furthermore, the weed is well established in many districts of South, north, and central Tigray. In Alamata district alone, about 10,000 hectares of the land has been infested with Parthenium hysterophorus. In much of the low lands of Wello, Parthenium hysterophorus has become the most dominant weed. In these areas, the weed has been reported in 42 districts. Even though there is no actual survey report on the total area of land infested in the region, the weed is also a serious problem in Oromia region. Currently, it is spreading at an alarming rate in East Shewa, Arsi, Ziway and Bale [39]. Generally, the distribution of Parthenium hysterophorus in Ethiopia is concentrated to the rift valley between Arba Minch and Dire dawa, stretching up along the road from Addis Ababa to the Eritrean boarder which invaded large arable and grazing lands (Figure 3).

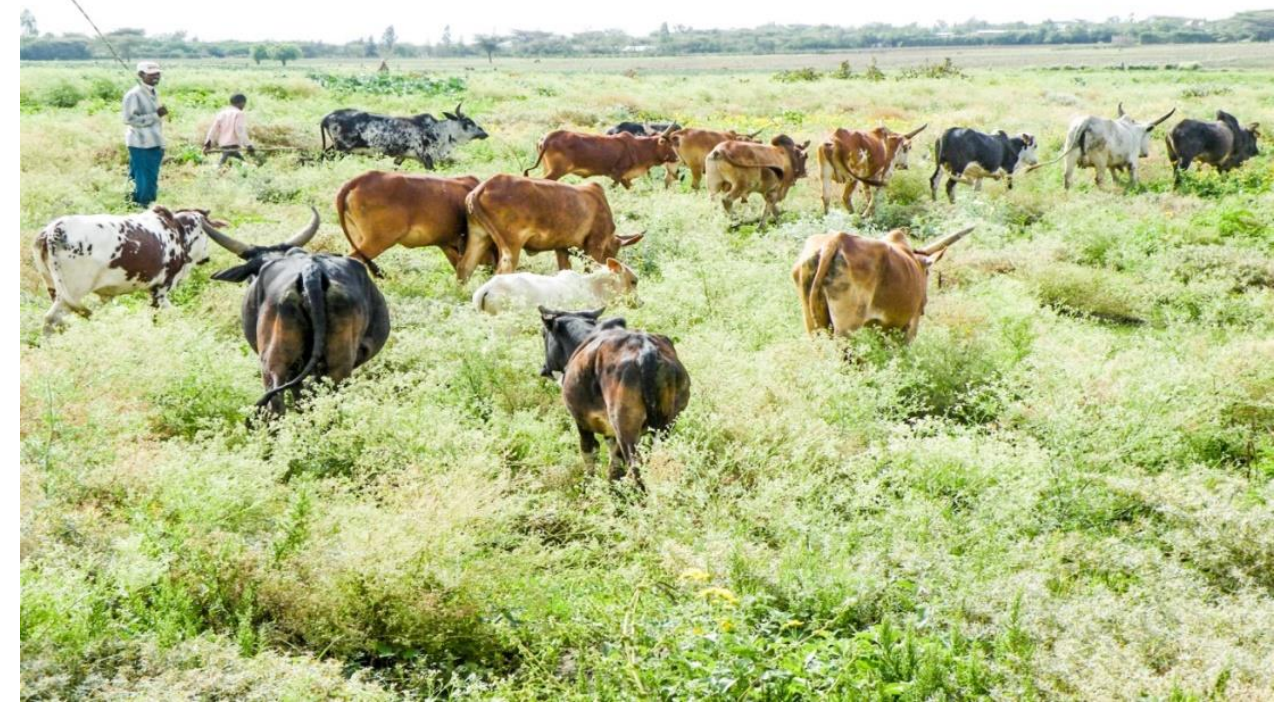

Figure 3: Parthenium weeds on Range Land (Image from: Google.com) 
Some researchers suggested Parthenium hysterophorus as blessed plant and managed through changing to the organic compost. [40] Reported how those invasive weed can support the organic agriculture by changing to compost before flowering.

Water hyacinth (Eichhornia crassipes) is a free floating aquatic weed that grows in fresh water, but may be rooted in the mud, from where it draws all its nutrients directly. It has been recognized as the most damaging aquatic weed in Ethiopia since its first presence in 1965 [41]. Compost making from Water hyacinth (Eichhornia crassipes), would be a better alternative to improve soil fertility. It can reduce chemical fertilizer load and expansion of water hyacinth. According to [42] Compost made using vermin compost recorded highest total nitrogen, organic carbon, phosphorous and potassium when compared to cattle manure and crop straw combination respectively. This report shows that water hyacinth has remarkable nutritive properties that can be used for the production of nutrient enriched compost. On the other hand the use of water hyacinth as compost materials has an advantage to maintain healthy aquatic system as well as a substitute for crop residue to make compost. Thus, if those systematic eradication is not applied, there would be many infrastructures like road and irrigation blockage and minimize their service years (Figure 4 ).
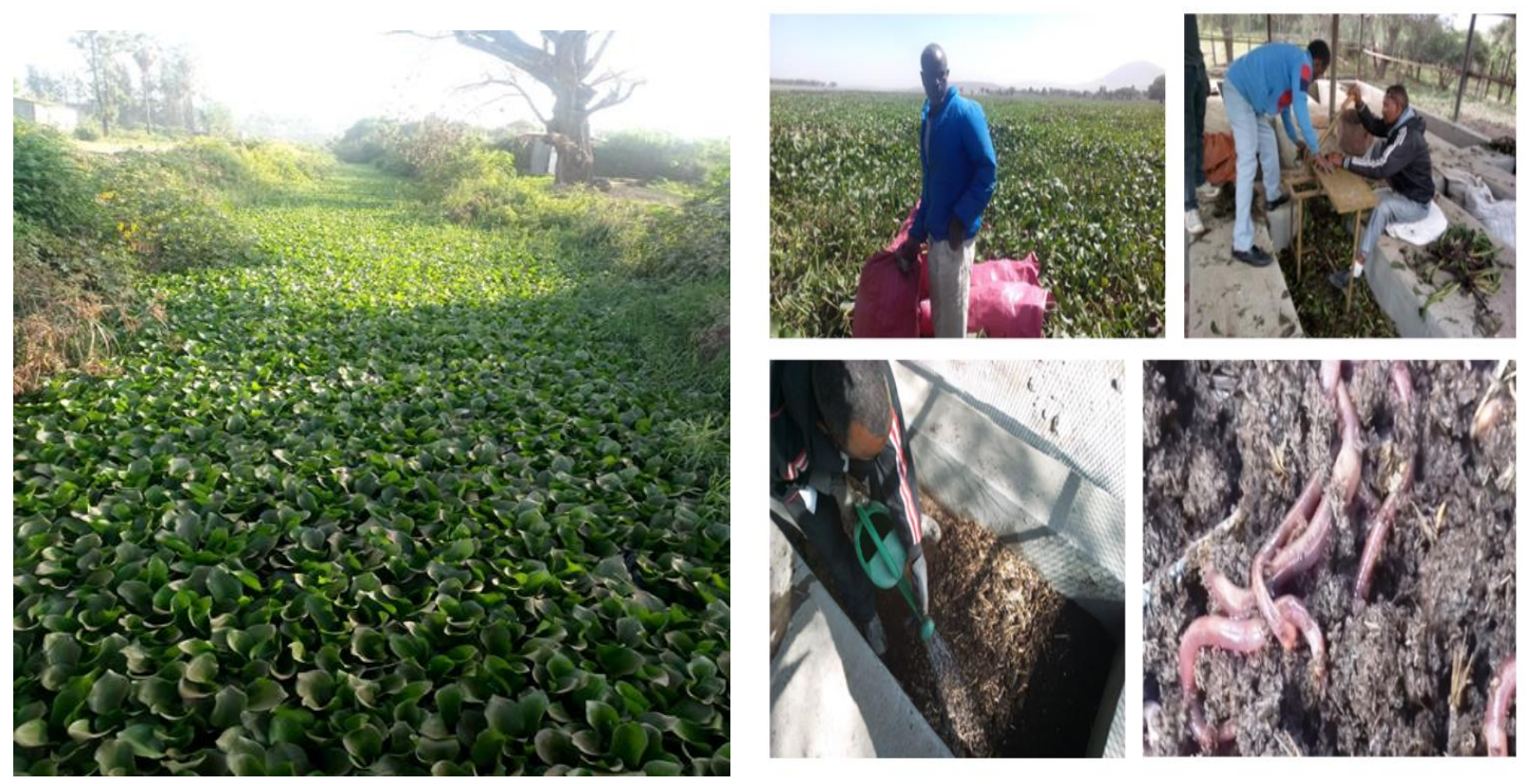

Figure 4: (a) Irrigation canal blocked by Water hyacinth, Wonji (Photo courtesy by: Tadie Girma Dadi)

(b) harvesting of water hyacinth, copping with chaff cutter mixing and vermiworm (Esenia fetoida) used (source: [42].

\section{Challenges to Perform Vermicomposting Technology in Ethiopia}

\subsection{Policy Direction, Financial and approaching strategies}

As a researcher we are witness for the overall challenges regarding to promoting organic fertilizers which paid less attention from policy developer to the end users. For instance [8] Report argued that the development planners, experts, extension agents, researchers and academicians' knowledge on vermi-composting and vermi-culturing is still very low to promote on large scale. In addition, the technical and financial support for the scaling up of Vermi-compost is still limited. Furthermore, the extension approaching due to leaning of Experts and extension agents to chemical fertilizers rather than organic fertilizers is the main surrender to adopt the technology.

\subsection{Predators, Parasites and pathogens of vermiworm}

Earthworms can be the target for a wide range of vertebrate predators, parasites and pathogens like of birds and ants, Protozoa and nematodes (Nematoda), bacteria, such as Spirochaeta sp. and Bacillus sp., and fungal have been reported to affect on the earth worms respectively [43]. 


\subsection{Vermiworm Handling problems}

The vermiworm has a negative tendency for too moist substrate and sunshine which paralyzing the worm. It needs series scientific follow to boost vermiworm and compost production which is the core problem in Ethiopian experience yet. Unwise way of feeding the worm and collecting the cast on appropriate time are the most lasting problems in Ethiopia [8].

\subsection{Influence of Environmental Factors on growth of vermiworm}

Earthworms have well defined limits of tolerance to environmental parameters, such as moisture and temperature, and that the wastes are processed much more efficiently within a relatively narrow range of favorable chemical and environmental conditions. If these limits are greatly exceeded, earthworms may move to more suitable zones in the waste, leave it, or die, so that these wastes are processed very slowly [43]. According to [44] the optimum temperature for Eseina fetida was $25^{\circ} \mathrm{C}$ and its temperature tolerance was between $0^{\circ} \mathrm{C}$ and $35^{\circ} \mathrm{C}$. Dendrobaena veneta had a rather low-temperature optimum and rather less tolerance to extreme temperatures. Similarly, the optimum range of moisture contents for most species has been reported to be between 50\% and 90\%. Eisenia fetida and Eisenia andrei can survive in moisture ranges between $50 \%$ and $90 \%$, but they grow more rapidly between $80 \%$ and $90 \%$ in organic wastes (See table 3).

Table 3: Optimal Conditions for Breeding Eseina fetida in Organic Wastes

\begin{tabular}{|l|l|}
\hline & Requirement \\
\hline Temperature & $15^{\circ} \mathrm{C}-20^{\circ} \mathrm{C}\left(\right.$ limits $\left.4^{\circ} \mathrm{C}-30^{\circ} \mathrm{C}\right)\left(59-68^{\circ} \mathrm{F}\right)\left(\right.$ limits $\left.39-86^{\circ} \mathrm{F}\right)$ \\
Moisture content & $80 \%-90 \%($ limits $60 \%-90 \%)$ \\
Oxygen & Aerobicity \\
Ammonia content of the waste & Low: $<1 \mathrm{mg} \cdot \mathrm{g}^{-1}\left(0.016 \mathrm{oz} .1 \mathrm{~b}^{-1}\right)$ \\
Salt content & Low: $<0.5 \%$ \\
pH & $5-9$ \\
\hline
\end{tabular}

Source: [44]

Lastly,[44] finding realize the epigeic earthworms are relatively tolerant to $\mathrm{pH}$ and can tolerate $\mathrm{pH}$ levels of 5-9, but when given a choice in the $\mathrm{pH}$ gradient, they move toward the more acid material, with a $\mathrm{pH}$ preference of 5.0. Ethiopia the land with -146 meter below sea level (Dalol) and 4620 meter above sea level (Ras Dashen) along with average minimum $6^{\circ} \mathrm{C}$ and maximum $26^{\circ} \mathrm{C}$ is very favored to promote the vermicomposting technology.

\section{Adaptive Earth Worms for Ethiopia Agro-Ecology}

Factually the worms that have been under using for vermicomposting purposes are categorized as common and commercial earth worms. Common earth worms are found in different area of the country with different local names and the commercial exotic worms are mainly distributed from Ambo Research Center. As we refer documented materials about this technology the (Red Wiggler) Eisenia fetida is the only successful exotic vermi-worm until the drawing together of this review paper. [45] Argued on the comparison of local and exotic (Eisenia fetida) earthworm species in different feed mixtures significantly affected the growth and production as well as the nutrient content of vermin compost produced in Assosa (Mid-lowland area). Among the three tested species (Eisenia fetida, Deberezeit (Eudrilus eugeniae and keshmando (Eudrilus eugeniae)) showed better performance and promised for culture with good growth and survival as well as production of quality vermicompost along different provided substrates to them. Therefore, species of earthworms with their preference of suitable substrate were: Debrezeit with khat and fruits peels, (Red Wiggler) Eisenia fetida with maize and khat and Keshmando with maize and fruit peels.

[12] Had performed the comparison of vermi-worm species and feed type at Tigray region highlands and their research result shown on the exotic earth worms (Red Wiggler) Eisenia fetida multiplication in numbers of worms and producing vermi-compost in period of time. Furthermore, output which conducted at the feedstocks and worm types 
are the primal preconditions for vermiculture, amount and quality of cast production. Comparatively Adet local earthworms produced quality vermi-compost and highest earthworm growth rate when fed on all feedstock's (Prosopis julifera, wheat straw, chickpea straw and khat straw). The weight of Esenia fetida doubled when they fed on prosopis julifera alone. In general, the standard (Eisenia fetida) from Ambo Agricultural research Center and Local earthworms (Adet and Wereta) showed feedstock preference in decreasing tendency for Prosopis julifera $<$ wheat straw $<$ chickpea straw $<$ khat straw.

\section{Conclusion and Recommendations}

Nature is a full of paradox. Adapting the real life with the independent and dynamic sort of nature is the best option. Ethiopia is rich in multi-unexploited Resource which may uplift the agrarian life forever. Developing the technologies to shift each problem to opportunity is the mandate of Researchers, Policy makers and the end users. Hence, vermicomposting technology is the meantime crosscutting issues which tend to lean the hope of developing country's farmers one step forward. In general term, the vermicomposting technology is new in Ethiopia and not adopted in a wide range. Many conducted researches were on small scales and needs further expansion in selecting the best worm species that well performed in each agro ecology of the country. Most of the researchers were used the exotic worm (Eisenia Fetida) and strongly recommending with its less accessibility for massive farmers in local area.

As a recommendation for researchers:

- Aiming on best local verm species that could easily accessible for farmers.

- Investigating the agro-ecology features relation with vermicomposting technology.

- Focusing on cereal crops residue characters to vermin-worm relation in central Ethiopia.

- Biological characterization of vermiworm is not yet furtherly identified.

For policy makers:

- Establishing vermicomposting centers in each farmers training and higher education center to cut off the inorganic fertilizer supplement and ecosystem management.

- $\quad$ Striving to have well trained manpower on this area.

- Increasing the awareness of local farmers to adapt the technology.

- Using Vermicompost production as nature based solution to pursue the sustainable natural resource management.

Author Contributions: Conceptualization, Tadie Girma Dadi and Hana Tamrat Gebirehiwot; writing original draft preparation, Hana Tamrat Gebirehiwot; writing review and editing, Tadie Girma Dadi. All authors have read and agreed to the published version of the manuscript.

Conflicts of Interest: The authors declare no conflict of interest.

\section{References}

1. Tamene L., Amede T., Tihara J., Tibebu D. and Schulz S.(eds.). A review of soil fertility management and crop response to fertilizer application in Ethiopia: Towards development of site-and context-specific fertilizer recommendation. International Centre for Tropical Agriculture 2017, CIAT Publication No. 443, 86 p.

2. Tolcha T., Midega T., Kumbi H. and Tola B. Effect of integrated inorganic and organic fertilizers on yield and yield components of Barley in Liben Jawi District. International Journal of Agronomy 2018, Vol.2018.

3. Kenea, F. T. and F. Gedamu. Response of garlic (Allium sativum L.) to vermicompost and mineral N fertilizer application at Haramaya, Eastern Ethiopia." African Journal of Agricultural Research 2018,13(2): 27-35.

4. Rashid Sh., Abera D., Agegnehu G., and Zelleke,G. Fertilizer and soil fertility potential in Ethiopia." International food policy institute: 2010.Working Paper.

5. Balemi T. Composition of different composts and vermicompost and effects of their application rates on growth parameters of pot grown tomato. African Journal of Agricultural Research 2017,12(18): 1514-1525.

6. Tesfu M., Heluf G., Kibebew K., Kebede W., Beneberu Sh., and Hiranmai Y. The integrated use of excreta-based vermicompost and inorganic NP fertilizer on tomato (Solanum lycopersicum L.) fruit yield, quality and soil fertility. International Journal of Recycling of Organic Waste in_Agriculture 2017, 6(1) :63-77. 
7. Kenea F., and Gedamu F. Effect of vermicompost on growth, quality and economic return of garlic (Allium sativum L.) at Haramaya District, Eastern Ethiopia. African Journal of Agricultural Research 2019, 14(35): 2159-2167.

8. Teka K., Githae E., Welday Y., and Gidey E.Vermi-composting for increased agricultural productivity, women empowerment and environmental sanitation in northern Ethiopia. AgriFoSe2030 Report 2019, (35) P45

9. Teka K., Berihu T., Amdu H., Araya T., and Nigussie S. Assessing Soil Nutrient Additions through Different Composting Techniques in Northern Ethiopia." Momona Ethiopian Journal of Science 2014, 6(2): 110-126.

10. Yadav R. H. Assessment of different organic supplements for degradation of Parthenium hysterophorus by vermin technology." Journal of Environmental Health Science and Engineering_2015, 13(1):44.

11. Argaw, A. and A. Mnalku. Vermicompost application as affected by Rhizobium inoculation on nodulation and yield of faba bean (Vicia faba L.). Ethiopian Journal of Agricultural Sciences 2017, 27(2): 17-29.

12. Getachew A., Gebreyes G., Tolera A., and Daniel M. Soil Fertility and Plant Nutrient Management, Ethiopian Institute of Agricultural Research 2018, Book. ISBN: 978-99944-66-52-8

13. Tekulu K., Tadele T., and Berhe T., Effect of vermicompost and blended fertilizers rates on yield and yield components of Tef (Eragrostis tef (Zucc.) Trotter).Journal of Soil Science and Environmental_Management 2019, 10 (6):130-141.

14. Anbessa B., Addisu T., and Dereje G. Effect of Inorganic and Organic Fertilizer Application on Growth and Yield of Maize and Soil Fertility in Assosa Zone. Soil Fertility and Plant Nutrient Management 2018, ISBN: 197.156.72.153

15. Biri A., Kaba S., Taddese F., and Dechassa N. Effect of Vermicompost and Nitrogen Application on Striga Incidence, Growth, and Yield of Sorghum [Sorghum bicolor (L.) Monech] in Fedis, eastern Ethiopia_International J. of Life Sciences 2016, 14 (3): 349-360.

16. Asgele K., Woldetsadik K., Gedamu F. Effect of inorganic NP fertilizers and vermicompost on growth, seed yield and yield components of onion (Allium cepa L.) at Maitsebri, Northern Ethiopia. Journal of Horticulture and Forestry_2018, 10(6): 89-96.

17. Ching L. Mitigating and Adapting to Climate Change through Ecological Agriculture, Penang: Third World Network 2011, ISBN: 978-967-5412-46-2.

18. Yadav A, and Garg VK. Industrial wastes and sludges management by vermicomposting. Reviews in Environmental Science and Bio/Technology 2011, 10(3): 243-276.

19. Abebe N., Thomas W.K., Sander B., and Andreas de N. Vermicomposting as a technology for reducing nitrogen losses and greenhouse gas emissions from small-scale composting. Journal of Cleaner Production 2016, 139: 429-439.

20. Mekonnen M. T., and Amsalu Z.T. Causes and impacts of Shankila River water pollution in Addis Ababa, Ethiopia. Environ Risk Assess Remediat_2018,_2 (4): 21-30.

21. Eriksson M., and Jonathan S. Causes and impact of surface water pollution in Addis Ababa, Ethiopia 2019, p. 74

22. Ingwani E., Gumbo T., and Gundo T. The general information about the impact of water hyacinth on Aba Samuel Dam, Addis Ababa, Ethiopia: Implications for ecohydrologists. Ecohydrology \& Hydrobiology 2010, 10(2-4): 341-345.

23. Rajiv K.S., Sunil H., Sunita A., Ravi A., and Emilio C. Vermiculture and waste management: study of action of earthworms Elsinia foetida, Eudrilus euginae and Perionyx excavatus on biodegradation of some community wastes in India and Australia. Environmentalist 2002, 22(3): 261-268.

24. Getnet M., and N. Raja. Impact of vermicompost on growth and development of cabbage, Brassica oleracea Linn. and their sucking pest, Brevicoryne brassicae Linn.(Homoptera: Aphididae). Research Journal of Environmental and Earth Sciences_2013, 5(3): 104-112.

25. Mengesha W. K., Powell S. M., Evans K. J., and Barry K. M. Diverse microbial communities in non-aerated compost teas suppress bacterial wilt. World Journal of Microbiology \& Biotechnology 2017, 33(3): 49-49.

26. Rani D., Ashok K., and Bishaw D. Organic farming and sustainable development in Ethiopia. Scientific Research and Essays 2007,2 (6): 199-203.

27. Kassie M.,Zikhali P.,Manjur K., and Edwards Sue. Adoption of organic farming technologies: Evidence from semi-arid regions of Ethiopia. Rapport nr: Working Papers in Economics_2008,_335:1403-2465.

28. Rameshwar, H. Y. and A. Argaw. Manurial value of khat waste vermicompost from Awday, Harar town, Ethiopia. International Journal of Recycling of Organic Waste in Agriculture 2016, 5(2): 105-111.

29. Teklay T., Mebrahtu G., Kiros G., Miruts H.,and Selamawit G.,Tomato Yield and Economic Performance Under Vermicompost and Mineral Fertilizer Applications. The Open Agriculture Journal 2018, 12(1):262-269.

30. Habebo, A. T. User Participatory Organic Waste And Grey Water Management Amidst Cultural Indifference To Cope With Increasing Effect Of Climate Change. 30th EPHA Annual Conference 2019.

31. Gessesse, D. Favouring a Demonised Plant: Khat and Ethiopian smallholder enterprises, Nordiska Afrikainstitutet 2013, 51(1):28.

32. Degefe G.,Mengistou S., and Mohammed S. Physico chemical evaluation of coffee husk, wastes of enset (Enset ventricosum), vegetable and khat (Catha edulis) through vermicomposting employing an epigeic earthworm Dendrobaena veneta (Rosa, 1886). African Journal of Biotechnology 2016, 15(20): 884-890. 
33. Tessema Y.A. Ecological and Economic Dimensions of the Paradoxical Invasive Species-Prosopis juliflora and Policy Challenges in Ethiopia. Journal of Economics and Sustainable Development 2012, 3(8).

34. Wubneh W. Y. Parthenium hystrophorus in Ethiopia: Distribution, Impact and Management-A Review. World Scientific News 2019, 130: 127-136.

35. Zuberi, M. I., Gosaye T., and Hossain S. Potential threat of alien invasive species: Parthenium hysterophorus L. to subsistence agriculture in Ethiopia. Sarhad Journal of Agriculture 2014, 30(1):117-125.

36. Wakjira M., Berecha G., and Tulu S. Allelopathic effects of an invasive alien weed Parthenium hysterophorus L. compost on lettuce germination and growth. African Journal of Agricultural Research 2009, 4(11): 1325-1330.

37. Fessehaie R. Water hyacinth (Eichhornia crassipes): A Review of its weed status in Ethiopia. Conference of the Ethiopian Weed Science Society, Journal of Arem, Addis Abeba 2005. V(6):105-111

38. Abay Challa Kuke and Kasahun Kitila Hunde. Evaluation of Water Hyacinth (Eichhornia Crassipes) Compost for Its Nutrient Content at Adami Tulu Agricultural Research Center. Innovative Techniques in Agriculture 2019, 3.4:690-696.

39. Dominguez J., and Edwards C.A. Relationships between composting and vermicomposting. Vermiculture Technology Earthworms, Organic Wastes, and Environmental Management_2010, 1: 11-26.

40. Edwards, C.A. Breakdown of animal, vegetable and industrial organic wastes by earthworms. Earthworms in waste and environmental management 2013, P21-31,

41. Getachew Z., Adisu T., Abeble L., and anbessa B. Vermicompost potential of common earthworms (Eudrilus eugeniae) and red wiggler (Eisenia fetida) worm on the decomposition of vari organic wastes. International Journal of Plant and Soil Science 2018, 24(3):1-13. 